scheme came into existence, under which an attempt was made to ensure that all newly published books were bought somewhere in the area. Afterwards, responsibilities under the scheme were assigned according to the resources of each library, and each library was also asked to become responsible for the biographies of persons connected with their special subjects. Later still, schemes were started among the public libraries of the Northern Region, the East Midlands (limited to books in foreign languages), Wales (for certain specialized books), and in April 1954, in the North-Western Region (in which seventy-five libraries participated, but periodicals and purchase of older books are excluded).

Mr. Hunt suggests that the most necessary future developments are likely to be concerned with increasing the provision of foreign books, and co. ordinating and improving the supply of periodicals. Such problems are mainly the concern of university and special libraries; but the various regional schemes of public library co-operation could easily be coordinated and improved by dividing the responsibilities for still higher degrees of specialization between the specializing libraries in each subject in each region on a systematic and orderly basis. This would give strong support to any co-ordination attempted by research institutions acting alone.

\section{AMERICAN PHILOSOPHICAL SOCIETY}

\section{YEAR BOOK FOR 1954}

$\mathrm{T}$

HE Year Book for 1954 of the American Philosophical Society* includes E. G. Conklin's brief history of the Society, its charter aud laws, reports of standing committees, and the usual lists of members and biographical memoirs, among which may be noted those of M. T. Bogert, Sir Henry Clay, K. T. Compton, H. E. Ives, T. Lyman, R. A. Millikan and H. A. Spoehr. The report of the Committee on Research lists 165 grants, totalling 144,770 dollars, and one conditional grant of 600 dollars, made during the year from the Penrose Fund. Six of these, totalling 8,300 dollars, were in astronomy, physics and chemistry ; thirty-six, totalling 29,195 dollars, in zoology, botany, anthropology, biochemistry, physiology, psythology and related sciences; forty, totalling 37,755 dollars, in history, political science, economics and sociology; and eighty-three, totalling 72,520 dollars, in ancient, medieval and literary history, archæology, philology, art, literature, etc. Eight grants, totalling 21,336 dollars, were made from the Johnson Fund and six grants, totalling 13,335 dollars, from the Daland Fund for Research in Physical Medicine.

Reports from recipients of grants occupy some two hundred and fifty pages of the report of the Committee on Research. Among the more detailed of these summaries may be noted those of $\mathrm{H}$. $\mathrm{B}$. Levi on recent progress in the field of radiocarbon dating; M. K. Hecht on the comparison of recent and fossil amphibian, reptilian and mammalian faunas in the Bahamas; A. Carr's survey of the zoogeography and migrations of sea turtles, which indicates that under present conditions the green turtle is likely to be extirpated from the Caribbean

* American Philosophical Society. Year Book, 1954. Pp. 605. (Philadelphia : American Philosophical Society, 1955.) within twenty years although it appears to be peculiarly amenable to conservation; $\mathbf{K}$. T. Guthe's study of the myosin adenosine triphosphate of the echinoderm Stichopus; and C. J. Heusser's studies of glacier fluctuation, forest succession and climatic variation in the Canadian Rockies and pollen profiles from the Queen Charlotte Islands, northern Vancouver Island and northern coastal British Columbia. R. Singer reports on studies of the Basidiomycetes of South America in European herbaria, and J. L. Angel on the evidence as to human biology, health and history in Greece obtained by careful study of human bones excavated in Greece ; M. J. Herskovitis reports on field work in sub-Saharan Africa to assess how pre-existing cultural patterns react to different rates of industrialization and technological innovation, within the limits of differing Colonial policies, while W. B. Schwab discusses the analysis of material collected in a socio-economic survey of the Yeruba community in Nigeria with the object of examining the interrelations of urbanization and acculturation.

D. R. Brown summarizes an investigation of the effects on cortical currents of organic damage to the brain by the use of a behavioural measure involving the kinesthetic figural after-effect which appears to support the assumption that the lesion introduced in a lobotomy sets up a temporary physiological disturbance in the cortex which will change the conductivity of the higher brain centres and therefore the kinesthetic after-effect. W. S. Verplanck describes an interchange of experimental techniques and theoretical structures between European ethologists and American psychologists; and L. S. Ciereszko gives an account of the determination of vanadium in tunicates and of acidity in Ascida nigra as well as the collection, identification and preparation of various tunicates, sponges and gorgonians. N. C. Li reports on metal complexes of peptides containing sulphur, H. W. Neuberg on the metabolism of phosphophenolpyruvate, F. W. Crane on the spores of Dryopteris, and G. T. Johnson on the Mississippi species of the Trypetheliaceae.

In the social sciences, D. W. Meinig describes and analyses the nature of man's contact with the major agricultural frontier of the Pacific north-west and the Columbia Plateau grain region from 1805 to about 1910 , and C. T. Mason an inquiry into the non-profit research institute and how it functions. In archæology, H. A. Carey reports on a study of the ancient Indian culture centring in the Casas Grandes Valley, north-west Chihuahua, Mexico; F. E. Day on early Islamic pottery related to that of Tarsus and 'Arija Hafir'; K. P. Kent on the textile industry of prehistoric south-western Pueblo peoples, particularly with regard to weaving in cotton; $R$. S. MacNeish on the development of agriculture and the concomitant development of civilization in MesoAmerica, Tamaulipas, Mexico; H. C. Palmatary on Brazilian, Swedish and American Tapago pottery; and A. N. Stilwell on pottery from the Potters' Quarter in Corinth. P. Drucker describes a study of intertribal organizations of the north-west coast of the United States, I. Greenwald a study of the history of goitre, and C. Eisele one of C. S. Peirce and the history of science. Investigations of the freshwater ostracods of South Carolina are described by E. Ferguson, taxonomic and ecologic researches on the ants of Nevada by A. G. Cole, and a detailed field study of spring Orthoptera in western and southwestern States by J. A. G. Rehn. 